\title{
ESP v2.0: enhanced method for exploring emission impacts of future scenarios in the United States - addressing spatial allocation
}

\author{
L. Ran ${ }^{1}$, D. H. Loughlin ${ }^{2}$, D. Yang ${ }^{1}$, Z. Adelman ${ }^{1}$, B. H. Baek ${ }^{1}$, and C. G. Nolte ${ }^{2}$ \\ ${ }^{1}$ University of North Carolina at Chapel Hill, Institute for the Environment, 100 Europa Dr., Chapel Hill, NC 27517, USA \\ ${ }^{2}$ US Environmental Protection Agency, Office of Research and Development, 109 T.W. Alexander Drive, Research Triangle \\ Park, NC 27711, USA
}

Correspondence to: D. H. Loughlin (loughlin.dan@epa.gov)

Received: 7 November 2014 - Published in Geosci. Model Dev. Discuss.: 13 January 2015

Revised: 20 May 2015 - Accepted: 23 May 2015 - Published: 17 June 2015

\begin{abstract}
The Emission Scenario Projection (ESP) method produces future-year air pollutant emissions for mesoscale air quality modeling applications. We present ESP v2.0, which expands upon ESP v1.0 by spatially allocating futureyear non-power sector emissions to account for projected population and land use changes. In ESP v2.0, US Census division-level emission growth factors are developed using an energy system model. Regional factors for populationrelated emissions are spatially disaggregated to the county level using population growth and migration projections. The county-level growth factors are then applied to grow a base-year emission inventory to the future. Spatial surrogates are updated to account for future population and land use changes, and these surrogates are used to map projected county-level emissions to a modeling grid for use within an air quality model. We evaluate ESP v2.0 by comparing US $12 \mathrm{~km}$ emissions for 2005 with projections for 2050 . We also evaluate the individual and combined effects of county-level disaggregation and of updating spatial surrogates. Results suggest that the common practice of modeling future emissions without considering spatial redistribution over-predicts emissions in the urban core and under-predicts emissions in suburban and exurban areas. In addition to improving multidecadal emission projections, a strength of ESP v2.0 is that it can be applied to assess the emissions and air quality implications of alternative energy, population and land use scenarios.
\end{abstract}

\section{Introduction}

Emission projections are often the dominant factor influencing the outcome of future-year air quality modeling studies (e.g., Tagaris et al., 2007; Tao et al., 2007; Avise et al., 2009). Thus, building plausible emission scenarios and correctly allocating emissions to modeling grids are critical steps in conducting those studies. The Emission Scenario Projection v1.0 (ESP v1.0) method, described by Loughlin et al. (2011), facilitates the development of future-year air pollutant emission inventories by producing US Census division level-, source-category- and pollutant-specific emission growth factors. For most emission categories, multiplicative emission growth factors are developed using the MARKet ALlocation (MARKAL) energy system model (Fishbone and Abilock, 1981; Loulou et al., 2004). These factors are applied to a base-year emissions inventory, such as the United States Environmental Protection Agency (US EPA) National Emissions Inventory (NEI) (US EPA, 2010), using the Sparse Matrix Operator Kernel Emission (SMOKE) model (Houyoux et al., 2000). The resulting future-year emission inventory is then temporally and spatially allocated to a gridded modeling domain for use by an air quality model such as the Community Multi-scale Air Quality (CMAQ) model (Byun and Schere, 2006), typically at $4-36 \mathrm{~km}$ grid resolution.

Since the release of ESP v1.0, a number of improvements to the method and its components have been made. For example, in ESP v1.0, pollutants represented explicitly in the MARKAL database were carbon dioxide $\left(\mathrm{CO}_{2}\right)$, nitrogen oxides $\left(\mathrm{NO}_{x}\right)$, sulfur dioxide $\left(\mathrm{SO}_{2}\right)$, and particulate matter with diameter less than $10 \mu \mathrm{m}\left(\mathrm{PM}_{10}\right)$. The pollutant cov- 
erage in the ESP v2.0 MARKAL database has been expanded to include carbon monoxide $(\mathrm{CO})$, methane $\left(\mathrm{CH}_{4}\right)$, nitrous oxide $\left(\mathrm{N}_{2} \mathrm{O}\right)$, volatile organic compounds (VOCs), $\mathrm{PM}$ with diameter less than $2.5 \mu \mathrm{m}\left(\mathrm{PM}_{2.5}\right)$, black carbon (BC), and organic carbon (OC). Furthermore, while the ESP v1.0 MARKAL database was calibrated to the 2006 Annual Energy Outlook (AEO) (US EIA, 2006), the ESP v2.0 MARKAL database used here is calibrated to AEO 2010 (US EIA, 2010), and the method accommodates MARKAL databases calibrated to more recent AEO projections. As a result, developments such as the economic recession of 2008 and the increased availability of natural gas can now be considered. Additional detail in the electric sector also facilitates consideration of coal plant retirements and improvements in the cost-effectiveness of renewables.

Another aspect of the method that has been improved is the spatial representation of future-year emissions. In ESP v1.0, the application of multiplicative emission growth factors resulted in emissions being grown (or shrunk) in place. This approach does not account for any spatial redistribution of emissions resulting from population shifts or land use changes. The grow-in-place assumption is common in air quality modeling applications, most of which project emissions only 5-15 years into the future (Woo et al., 2008; Zhang et al., 2010). For modeling time horizons within this range, the grow-in-place assumption may be reasonable in light of the many other uncertainties associated with predicting future emissions. The EPA's Office of Research and Development (ORD) is increasingly interested in air quality modeling applications that extend well beyond 2030, however. In its Global Change Air Quality Assessment, ORD examined the impacts of climate change on air quality through 2050 (e.g., Nolte et al., 2008; US EPA, 2009b; Weaver et al., 2009). Similarly, the GEOS-Chem LIDORT Integrated with MARKAL for the Purpose of Scenario Exploration (GLIMPSE) framework is being used to examine climate and air quality management strategies through 2055 (Akhtar et al., 2013). The rationale for growing emissions in place is weaker when modeling over multi-decadal time horizons, where trends such as population growth and migration, as well as urbanization, may result in a very different future spatial distribution of emissions.

Land use change models are useful tools for investigating alternative assumptions regarding the spatial distribution of future-year emissions. For example, the Integrated Climate and Land Use Scenarios (ICLUS) model (Theobald, 2005; US EPA, 2009a; Bierwagen et al., 2010) was developed to provide a consistent framework for producing future-year population and land use change projections. ICLUS outputs have been generated over the US for a base case scenario, as well as several alternatives that are consistent with those described in the Intergovernmental Panel on Climate Change (IPCC) Special Report on Emission Scenarios (Nakicenovic and Swart, 2000).

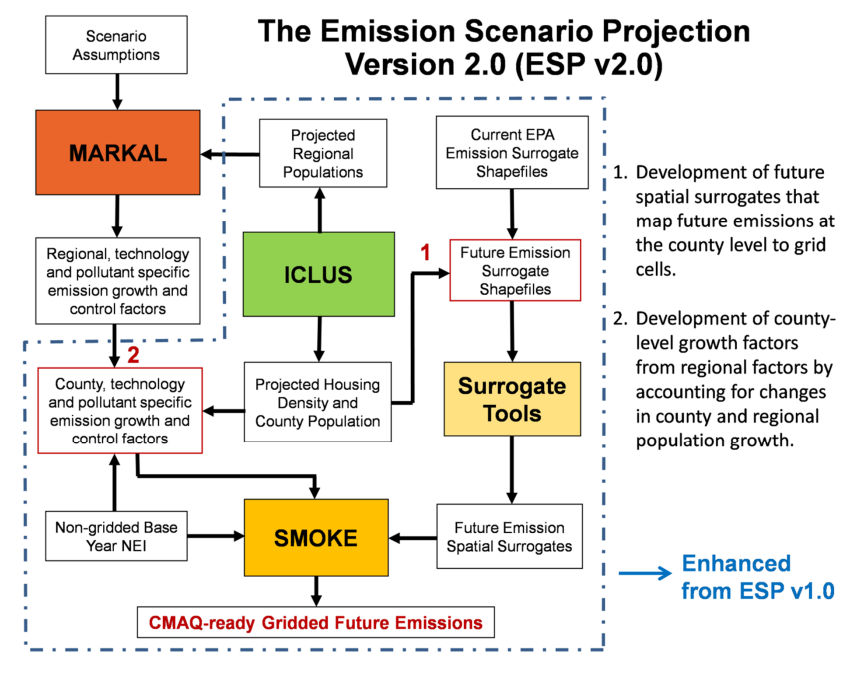

Figure 1. Schematic diagram showing components of the Emission Scenario Projection v2.0 system. Dashed blue box contains enhancements from ESP v1.0.

The key advancement of ESP v2.0 is the integration of ICLUS results to adjust the spatial allocation of future-year emissions in the residential, commercial, transportation, and agricultural sectors. ICLUS results are integrated into ESP v2.0 in three places. First, we use ICLUS population projections to adjust energy demands in MARKAL, including passenger vehicle miles traveled, lumens for lighting, and watts per square foot of space conditioning. Second, countylevel population projections also are used to disaggregate the regional emission growth factors derived from MARKAL into county-level growth factors. Finally, ICLUS outputs are used to develop new future-year spatial surrogates that map county-level emissions to an air quality modeling grid. The incorporation of ICLUS into ESP v2.0 is depicted in Fig. 1. The two steps associated with spatial allocation of emissions are listed as 1 and 2 in the figure.

The objective of this paper is to describe, demonstrate and evaluate the new spatial allocation features within ESP v2.0. First, the typical approach for spatial allocation in emission processing is described. Next, the new spatial allocation method is presented and evaluated. The method is then applied using an experimental design that isolates separately the impacts of using projected spatial surrogates and those of mapping regional growth factors to the county level. Conclusions and future plans for ESP v3.0 are presented in the last section.

\section{Background}

In most air quality modeling applications with CMAQ, the SMOKE model is used to transform an emission inventory, such as the NEI, from a textual list of sources and their respective annual emissions to a gridded, temporally allo- 
cated, and chemically speciated air quality model-ready binary file. Major steps in the generation of future emissions for an air quality model include the application of multiplicative emission growth and control factors to produce a futureyear emission inventory, temporal allocation of emissions by season, day and hour, and spatial allocation of hourly emissions onto a 2-dimensional grid over the modeling domain. A major component of the spatial allocation process is the use of other high-resolution data, such as census block group population or road networks, as surrogates to map countylevel emissions to grid cells.

Spatial surrogate computation for emission allocation is rarely mentioned in the documentation of air quality modeling studies. In the US, surrogate shapefiles (a standard file format for representing spatial data) are released by the US EPA Emissions Modeling Clearinghouse and are used to compute spatial surrogates to be used in SMOKE. Most of the surrogate shapefiles used at the time this analysis was conducted were created from 2000 census data (e.g., population and roads), as well as many other spatial data sets (such as building square footage and agricultural areas) that were generated around that time period. Note that the spatial surrogate shapefiles were subsequently updated in the $2011 \mathrm{EPA}$ modeling platform (US EPA, 2011, 2014a, b).

The surrogate shapefiles are processed to create gridded surrogates using the Surrogate Tools software package (Ran, 2015), a part of the Spatial Allocator (SA) system (UNC, 2014a). Figure 2 provides an example of the computation of a population-based spatial surrogate for a $12 \mathrm{~km}$ grid cell within Wake County, North Carolina, which includes the state's capital, Raleigh.

The total population range for each census block group area for Wake County and some adjacent counties (dark purple boundaries) in North Carolina is displayed. The surrogate value for any grid cell $(i)$ and county $(j)$ is computed as

SurrogateValue $(i, j)=\frac{\operatorname{SurrogateAttribute}(i, j)}{\sum_{i} \operatorname{SurrogateAttribute}(i, j)}$.

Wake County's total population, found by summing the population of each of its census block groups, was 627846 in 2000. A population of 98681 lived within the grid cell indicated by the arrow. The population-based spatial surrogate value for this grid cell and county is calculated as $98681 / 627846$, or 0.1572 . Thus, $15.72 \%$ of Wake County population-related emissions are allocated to this grid cell.

Spatial surrogate values always range from 0 to $1 ; 0$ indicates that no emissions are allocated to the grid cell (e.g., the grid cell does not intersect the county), and 1 indicates that all the county's emissions are allocated to the grid cell (e.g., the county is completely located within the grid cell). While the example grid cell lies within just one county, quite often a grid cell can cross multiple county boundaries. When this happens, a weighting method (area for polygons, length for lines, or number of points) is used.

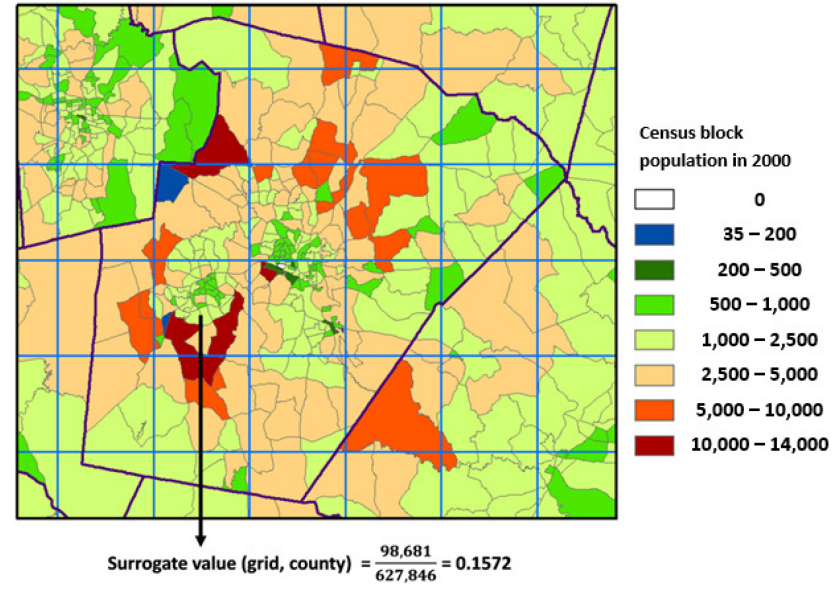

Figure 2. Population-based spatial surrogate computation for CMAQ $12 \mathrm{~km}$ modeling grid (blue cells) over Wake County (dark purple polygon), North Carolina area, from the 2000 census population at the census block group level (grey color polygons).

As of April 2014, the EPA has 91 different spatial surrogate shapefiles (e.g., population, housing, urban primary road miles) available via the EPA Emissions Modeling Clearinghouse (US EPA, 2014b). Since each surrogate has to be generated for each modeling grid domain and air quality modeling often includes multiple nested domains, the Surrogate Tools and their associated quality assurance functions make surrogate computation much easier for preparing emission input to air quality models.

Accurate spatial allocation is particularly important for finer-resolution modeling (e.g., $12 \mathrm{~km}$ or less) when multiple modeling grid cells are located within a county. While most previous CMAQ studies of future air quality have been conducted at relatively coarse resolutions $(\geq 36 \mathrm{~km})$ (Hogrefe et al., 2004; Tagaris et al., 2007; Nolte et al., 2008), finer resolutions are becoming more common with the rapid advancement of computing capabilities (Zhang et al., 2010; Gao et al., 2013; Trail et al., 2014). Thus, considering landscape changes due to human activities becomes particularly important in emission spatial allocation for high-resolution air quality modeling over long time horizons into the future.

\section{Method}

Spatial allocation in ESP v2.0 involves the two-step process displayed in Fig. 1. The models used in the method are listed and described briefly in Table 1 . For this paper, the method is demonstrated for a 2050 emission scenario, projecting 2005 base-year emissions using growth factors from MARKAL. We use ICLUS-produced population and housing density projections that assume county-level population growth in line with the US Census Bureau projections and a land use development pattern that follows historical trends 


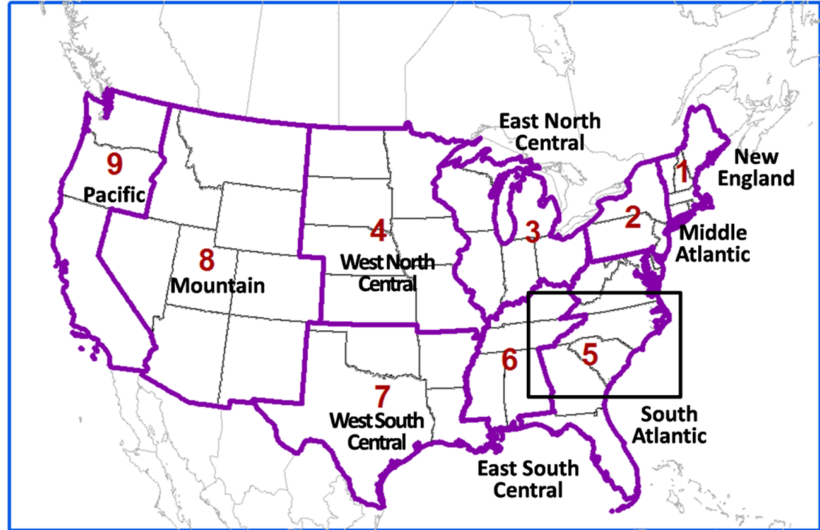

Figure 3. CMAQ $12 \mathrm{~km}$ modeling domain (blue box) showing nine MARKAL emission projection regions (dark purple) and the Southeast area (black box).

(US EPA, 2009a). Following the business-as-usual (BAU) development assumption, the method is applied to the conterminous US (CONUS) study area, with additional analysis conducted on the southeastern US. The MARKAL emission projection regions, CMAQ $12 \mathrm{~km}$ modeling domain, and the Southeast area are depicted in Fig. 3. The grid uses a Lambert conformal conic projection with 299 rows and 459 columns.

Figure 4 shows county-level population growth factors over the CONUS as well as 2005 and 2050 housing densities in the North Carolina, South Carolina, and Georgia areas. In the ICLUS projection, there is a distinct trend of population shifts towards big cities (e.g., Atlanta, Georgia and Charlotte, North Carolina) and a resulting increase in housing density around those urban areas. In general, county populations increase in most southern and coastal counties but decrease in northern and inland rural counties. The approaches for using these ICLUS projections to disaggregate regional emission growth factors and create future-year spatial surrogates are presented below.

\subsection{Developing county-level emission growth factors}

MARKAL outputs include regional growth factors for energy-related source category codes (SCCs). SMOKE projection packets with growth factors for each species and source category of interest were generated, as described by Loughlin et al. (2011). The six emission source sectors (US EPA, 2011) included in this projection were

1. point sources from the electric generating utility (EGU) sector

2. non-EGU point sources (e.g., airports)

3. remaining non-point sources (area sources not in agriculture and fugitive dust sectors)

4. on-road mobile sources (e.g., light duty vehicles)
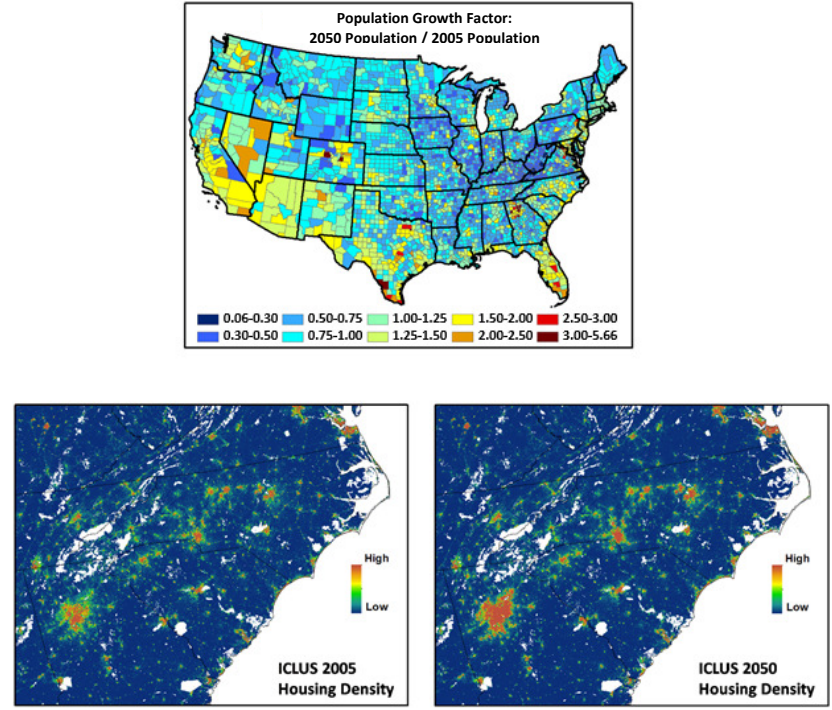

Figure 4. County-level population growth factors (2050/2005) (top) and ICLUS housing densities for 2005 and 2050 (bottom) for the Southeast area shown in Fig. 3. Areas in white are designated as undevelopable.

5. non-road mobile sources (e.g., construction equipment)

6. mobile emissions from aircraft, locomotives, and commercial marine vessels.

Though MARKAL-generated regional growth factors capture large-scale emission growth patterns, they do not capture variation in growth from one state to another or from one county to another within the region. To capture this spatial variation while maintaining the overall regional growth pattern from MARKAL, we introduce an adjustment calculation.

Let $F_{\mathrm{p}}$ denote the regional population growth factor and $f_{\mathrm{p}}$ denote the county-level population growth factor. The ratio of $f_{\mathrm{p}}$ over $F_{\mathrm{p}}$ captures the relative population growth rate of a county in comparison to its region (e.g., $f_{\mathrm{p}} / F_{\mathrm{p}}=1$ means the same growth rate, and $f_{\mathrm{p}} / F_{\mathrm{p}}>1$ means the county population growth is faster than the regional average growth). The regional emission growth factor $F_{\mathrm{e}}$ is adjusted by this ratio in computing the initial county emission growth factor $f_{\mathrm{e}}^{\prime}$ :

$f_{\mathrm{e}}^{\prime}(r, j, \mathrm{SCC}, s)=F_{\mathrm{e}}(r, \operatorname{SCC}, s) \cdot \frac{f_{\mathrm{p}}(r, j)}{F_{\mathrm{p}}(r)}$,

where $r$ is the region, $j$ is a county within $r$, and $s$ is the species. To ensure that the total regional projected emission is preserved after applying the county-level growth factors, the projected county emissions are re-normalized as

$$
\begin{gathered}
e_{2050}(r, j, \mathrm{SCC}, s)=\left[f_{\mathrm{e}}^{\prime}(r, j, \mathrm{SCC}, s) \cdot e_{2005}(r, j, \mathrm{SCC}, s)\right] \\
\cdot R_{\mathrm{re}}(r, \mathrm{SCC}, s),
\end{gathered}
$$


Table 1. Models used in the ESP v2.0 method.

\begin{tabular}{|c|c|}
\hline Model & Description \\
\hline MARKAL & $\begin{array}{l}\text { MARKet ALlocation (MARKAL) is an energy system optimization model (Loulou et al., 2004). We use } \\
\text { MARKAL with the ESP v2.0 database to characterize scenarios of the transition of the US energy system } \\
\text { from } 2005 \text { through } 2055 \text { in 5-year increments. ESP v2.0 is an updated version of the EPAUS9r_2010_v1.3 } \\
\text { MARKAL database (Lenox et al., 2013). The following major sectors are included: electricity production, re- } \\
\text { fineries, other energy-intensive industries, residential, commercial, and transportation. Spatial coverage is the } \\
\text { US, and spatial resolution is the US Census division. Outputs include regional-level, energy-related technology } \\
\text { penetrations, fuel use, and emissions of air pollutants and greenhouse gases. The ESP v2.0 baseline scenario is } \\
\text { calibrated to approximate the AEO 2010. The primary environmental regulations included in the baseline are } \\
\text { the Cross State Air Pollution Rule (CSAPR), Tier II mobile emission requirements, and the corporate average } \\
\text { fuel efficiency standard that requires } 54.5 \text { miles per gallon by 2025. Regulations that have not been finalized are } \\
\text { not included. }\end{array}$ \\
\hline ICLUS & $\begin{array}{l}\text { The Integrated Climate and Land Use Scenarios (ICLUS) model is used to develop US population and land } \\
\text { use projections through } 2100 \text { (US EPA, 2009a). The demographic model consists of a cohort-component model } \\
\text { and a gravity model. Together, these produce future county-level population estimates. A land use change } \\
\text { model then computes corresponding housing density at the hectare resolution, or } 10000 \mathrm{~m}^{2} \text {. Input assumptions } \\
\text { regarding household size and travel times can be adjusted to allow different scenarios to be represented. We use } \\
\text { a baseline scenario intended to be generally consistent with US Census Bureau projections. }\end{array}$ \\
\hline SMOKE & $\begin{array}{l}\text { The Sparse Matrix Operator Kernel Emissions (SMOKE) modeling system is used to transform an emissions } \\
\text { inventory into the emissions format needed for air quality modeling (UNC, 2014b). Specific steps carried out } \\
\text { by SMOKE typically include applying growth and control factors, spatially allocating emissions to a modeling } \\
\text { grid, temporally allocating emissions to represent seasonal and diurnal patterns, and speciating emissions to } \\
\text { provide more detail and account for additional factors such as temperature. }\end{array}$ \\
\hline Surrogate tools & $\begin{array}{l}\text { A set of programs used to develop spatial surrogate files for SMOKE (UNC, 2014a). These surrogates are then } \\
\text { used to map emissions to grid cells. }\end{array}$ \\
\hline CMAQ & $\begin{array}{l}\text { The Community Scale Air Quality (CMAQ) modeling system is used to characterize meteorology, pollutant } \\
\text { transport and chemical transformation, and resulting air pollutant concentrations (UNC, 2012). CMAQ can } \\
\text { be applied at a variety of scales, and is commonly used for urban, state, and regional air quality modeling } \\
\text { applications within the US and around the world. }\end{array}$ \\
\hline
\end{tabular}

where $e_{2005}$ and $e_{2050}$ are county-level emissions for 2005 and 2050 and $R_{\text {re }}$ is the ratio of regional emissions computed using regional growth factors to regional emissions derived from county growth factors:

$$
R_{\mathrm{re}}(r, \mathrm{SCC}, s)=\frac{F_{\mathrm{e}}(r, \mathrm{SCC}, s) \cdot \sum_{j} e_{2005}(r, j, \mathrm{SCC}, s)}{\sum_{j} f_{\mathrm{e}}^{\prime}(r, j, \mathrm{SCC}, s) \cdot e_{2005}(r, j, \mathrm{SCC}, s)} .
$$

The final county emission growth factors $\left(f_{\mathrm{e}}\right)$ are then computed as

$f_{\mathrm{e}}(r, j, \mathrm{SCC}, S)=\frac{e_{2050}(r, j, \mathrm{SCC}, s)}{e_{2005}(r, j, S C C, s)}$.

For source categories expected to have emission changes correlated with population changes, the resulting set of $f_{\mathrm{e}}(r, j, \mathrm{SCC}, s)$ factors are then used to grow the matching county-level emissions into the future. A spreadsheet with example calculations is included in the Supplement that accompanies this manuscript.
Changes in the spatial distribution of some emissions will not necessarily be correlated with population shifts, however. For example, we use regional emission growth factors, $F_{\mathrm{e}}(r, \mathrm{SCC}, s)$, for electric utilities, large external combustion boilers, and petroleum refining.

We applied ESP v2.0 to grow the 2005 NEI (US EPA, 2010) inventory to 2050. Figure 5 displays representative county-level emission growth factors. The two plots on the left are the MARKAL regional growth factors for $\mathrm{NO}_{x}$ from highway light duty gasoline vehicles (LDGVs) and for $\mathrm{SO}_{2}$ from residential stationary source fuel combustion, both of which would be expected to be correlated with population. The overall regional emission trends are driven by population growth, fuel switching and regulations that limit emissions. The county-level growth factors illustrate the effects of projected county-by-county population changes on these overall trends. Using county-level emission growth factors, we then generated SMOKE projection packets and used SMOKE to grow the emission inventory to 2050 . 

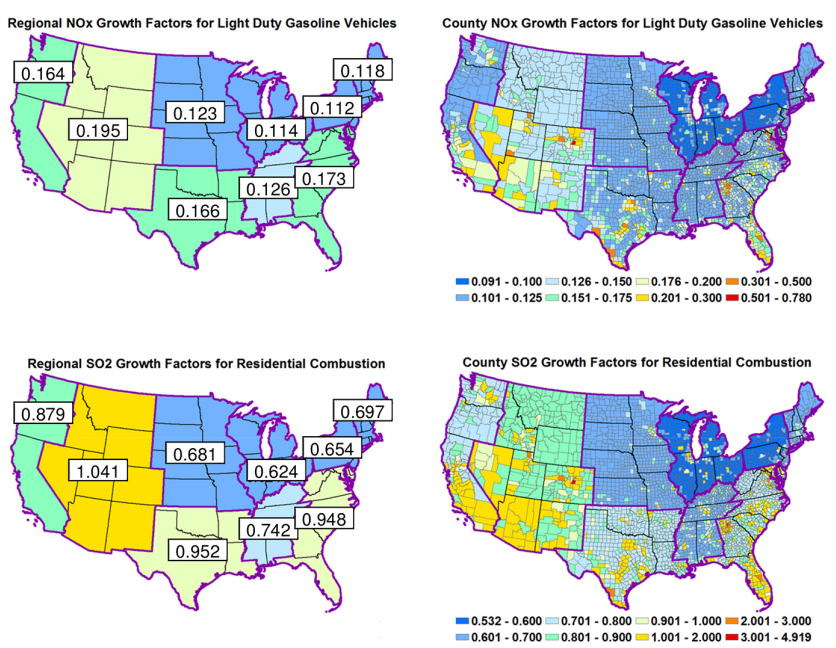

Figure 5. Light duty gasoline vehicle (LDGV) regional $\mathrm{NO}_{x}$ growth factors, generated by MARKAL, are shown in the top left panel. The top right panel shows corresponding county-level growth factors after adjustments are made to account for ICLUS countylevel population changes. Similarly, the bottom two panels show regional- and county-level $\mathrm{SO}_{2}$ growth factors for residential combustion, before and after population-based adjustments have been made.

\subsection{Updating surrogate shapefiles and emission surrogates}

The next step in spatial allocation is to create surrogate shapefiles using ICLUS-projected population and housing density. Standard EPA population and housing surrogate shapefiles are slightly different from 2005 ICLUS data. To avoid this discrepancy and ensure that surrogate shapefiles are generated consistently for comparison, ICLUS data are used to develop both the 2005 base and the 2050 shapefiles.

\subsubsection{Surrogate shapefiles}

Using ICLUS data, we created four new surrogate shapefiles for both 2005 and 2050. The first shapefile contains census block group polygons with associated population, housing units, urban, and level of development (e.g., no, low or high). The census polygon boundaries are based on the EPA 2002 population surrogate shapefiles. For each census block group, ICLUS housing units are spatially allocated to the census polygon using the area weighted method. Then, ICLUS county population is allocated to each census block group within a county according to the fraction of the county's housing units within that block group. Using ICLUS outputs for 2000, 2005, 2040, and 2050, we computed housing unit changes from 2000 to 2005 and from 2040 to 2050, which are needed for housing unit change surrogate computations for 2005 and 2050. For both 2005 and 2050, we classified census block groups as urban if their ICLUS-produced population density per square mile is $\geq 1000$. This criterion
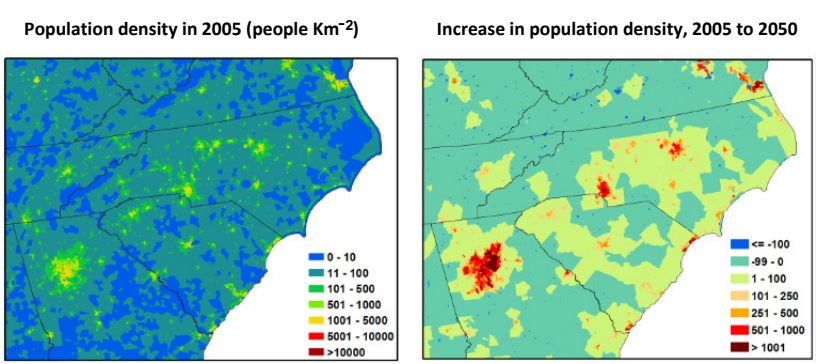

Urban areas (shown as red), 2005

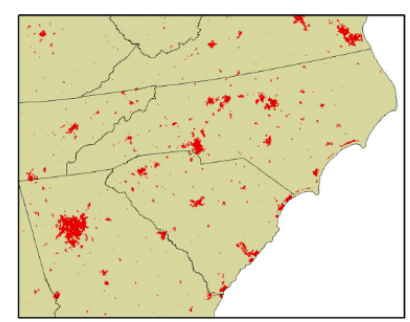

Additional urban areas (red), 2005 to 2050

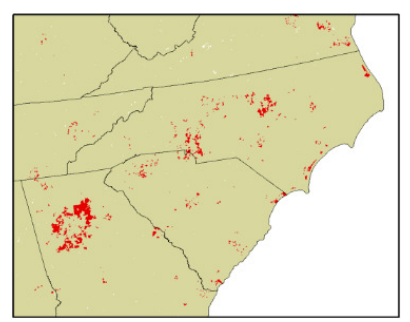

Figure 6. ICLUS population density and urban shapefiles for 2005 are shown on the left. Difference plots indicating ICLUS-predicted changes to these metrics from 2005 to 2050 are shown to the right.

is partially consistent with the US Census Bureau's definition of an urban area although, for simplicity, we did not use the Census Bureau's requirement of the surrounding area having a total population of 50000 or more. In addition, census block groups were classified into no, low, or high development areas based on housing density.

Figure 6 shows the change in population and urban surrogate shapefile data over the Southeast region between 2005 and 2050. The figure indicates expansion of urban areas, including Atlanta, Charlotte, Greensboro, and Raleigh. However, some rural areas, particularly in the north and south of this region, display slightly decreasing population densities.

The second surrogate shapefile we generated contains road networks. Though road networks are likely to expand in the future, it is very difficult to project future road networks. We use existing current road surrogate shapefiles with the ICLUS-identified urban areas to classify roads into four categories: rural and urban primary roads and rural and urban secondary roads. These categories are required for surrogate computation for mobile emission allocations. The third surrogate shapefile we generated contains rural land classification. We created this shapefile from the EPA 2002 rural land surrogate shapefile using urban and non-urban areas identified in the first shapefile. The last surrogate shapefile we created contains agricultural land classes. This shapefile was created from the EPA 2002 agricultural land surrogate file by excluding urban areas identified in the first shapefile. 
Table 2. ICLUS-based surrogates generated for 2005 and 2050.

\begin{tabular}{lr}
\hline Surrogate name & Surrogate code \\
\hline Population & 100 \\
Urban population & 110 \\
Rural population & 120 \\
Housing change & 130 \\
Housing change and population & 137 \\
Urban primary road miles & 140 \\
Rural primary road miles & 200 \\
Urban secondary road miles & 210 \\
Rural secondary road miles & 220 \\
Total road miles & 230 \\
Urban primary plus rural primary road miles & 240 \\
0.75 total roadway miles plus 0.25 population & 255 \\
Low intensity residential & 300 \\
Total agriculture & 310 \\
Rural land area & 400 \\
Residential - high density & 500 \\
\hline
\end{tabular}

\subsubsection{Surrogates computation}

With the ICLUS-based surrogate shapefiles, we computed 2005 and 2050 surrogates using the Surrogate Tools. As noted previously, EPA employs a set of 65 spatial surrogates to allocate emissions from various source sectors to a gridded modeling domain. The 17 surrogates listed in Table 2 were computed using the four ICLUS-based shapefiles. We assumed that the other 48 surrogates remain unchanged from current EPA surrogates.

The percentage change of ICLUS population-based surrogates from 2005 to 2050 is shown in Fig. 7. As expected, population-based surrogate changes on the $12 \mathrm{~km}$ grid follow the trends shown in Fig. 4. Since surrogates for the grid cells intersecting a county necessarily sum to 1 , large surrogate increases (red colors) in some grid cells are often accompanied by large decreases (blue colors) in other grid cells within the same county. Large percentage changes are particularly obvious in sparsely populated areas, such as parts of California, Nevada, Arizona, New Mexico, Texas, and Florida. The mean change of population-based surrogates from 2005 to 2050 is $6.23 \%$, although a standard deviation of $46.96 \%$ indicates a wide range across the grid cells.

\section{Application}

We applied ESP v2.0 to generate 2005 and 2050 CMAQready gridded emission files. Only the six sectors listed above from the 2005 NEI were used in the 2050 projection. Emissions from any SCCs not included in the projection packets were held constant from 2005. We used the Emission Modeling Framework (Houyoux et al., 2006) to conduct SMOKE modeling tasks.

Next, two additional 2050 inventories were created, one using the regional growth factors from MARKAL and one using the surrogates based upon 2005 ICLUS results. The
Table 3. Standard and sensitivity runs for ESP v2.0 demonstration and evaluation.

\begin{tabular}{llll}
\hline $\begin{array}{l}\text { Inventory } \\
\text { ID }\end{array}$ & $\begin{array}{l}\text { Inventory } \\
\text { year }\end{array}$ & $\begin{array}{l}\text { ICLUS } \\
\text { surrogates }\end{array}$ & $\begin{array}{l}\text { Growth } \\
\text { factors }\end{array}$ \\
\hline $\begin{array}{l}\text { Base } \\
\text { Future }\end{array}$ & 2005 & 2005 & NA \\
Future05Surr & 2050 & 2050 & County \\
FutureRegGF & 2050 & 2005 & County \\
\hline
\end{tabular}

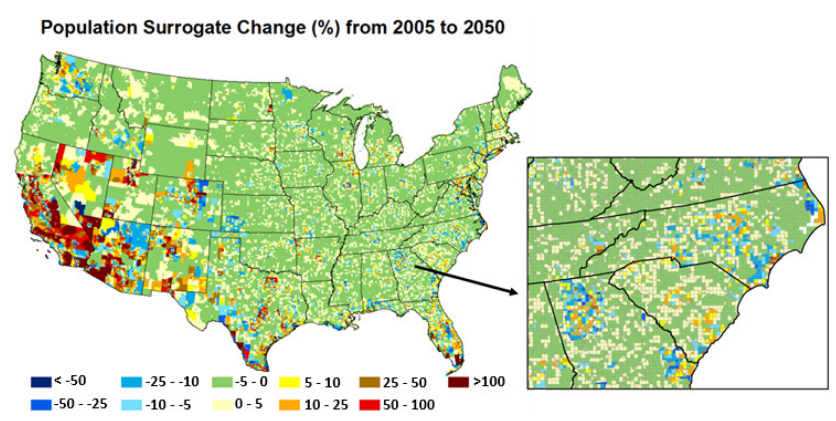

Figure 7. Population-based surrogate change (\%) for CMAQ $12 \mathrm{~km}$ modeling grids.

four resulting gridded inventories that were developed are listed in Table 3.

Future represents the result of the full ESP v2.0 projection method. Comparing Future with Base thus reveals the projected changes in both magnitude and location of emissions over the 45-year period. Comparing Future with $\mathrm{Fu}$ tureRegGF isolates the effects of disaggregating regional growth factors to the county level. Similarly, comparing $\mathrm{Fu}$ ture with Future05Surr identifies spatial changes resulting from updating the future spatial surrogates.

The fractional difference (FD) metric is used to evaluate grid-level differences among the inventories. For a model grid cell $(i)$ and species $(s)$, the FD is calculated as

fractional difference $(\mathrm{FD})=$

$$
2 \cdot\left[\frac{e_{\mathrm{A}}(i, s)-e_{\mathrm{B}}(i, s)}{e_{\mathrm{A}}(i, s)+e_{\mathrm{B}}(i, s)}\right] \cdot 100,
$$

where $e_{\mathrm{A}}(i, s)$ and $e_{\mathrm{B}}(i, s)$ are the emissions of species $s$ in grid cell $i$ for the gridded inventories, $\mathrm{A}$ and $\mathrm{B}$, that are being compared. FD is generally called fractional bias when it is used to evaluate errors of modeling results against observations (e.g., Morris et al., 2006). FD is a symmetric metric ranging from -200 to $+200 \%$. A value of $67 \%$ for FD represents that $e_{\mathrm{A}}$ is larger than $e_{\mathrm{B}}$ by a factor of 2 , while an FD of 0 means that values are the same. The mean and standard deviation of FD values across groups of grid cells provide information about the magnitude and variability of differences between two gridded inventories. Other statistical metrics can be used to evaluate differences from one gridded 


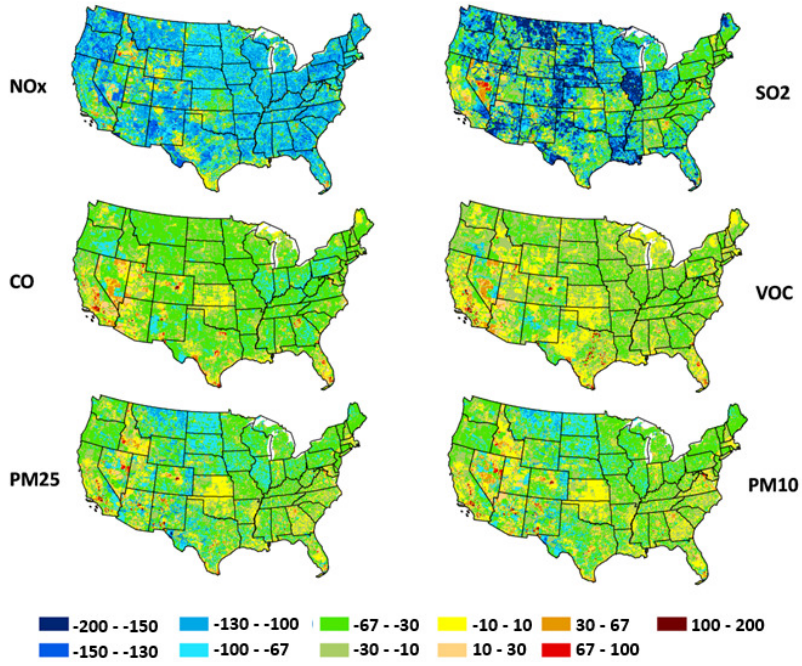

Figure 8. FD (\%) of annual emissions, Future minus Base, over the $12 \mathrm{~km}$ CONUS domain. (Future: 2050 inventory, 2050 surrogates, county growth factors; Base: 2005 inventory, 2005 surrogates).

inventory to another. Several such metrics are described and applied in the Supplement.

\subsection{Base and future emission differences}

Figure 8 shows FDs between annual emissions in the Base and Future for each of the six projected pollutant species. These plots reflect the combined effects of population growth and migration, economic growth and transformation, fuel switching, technological improvements, land use change, and various regulations limiting emissions (Loughlin et al., 2011). Most of the US has more than a $30 \%$ reduction (green and blue colors) in modeled $\mathrm{NO}_{x}, \mathrm{SO}_{2}, \mathrm{CO}, \mathrm{VOCs}, \mathrm{PM}_{2.5}$ and $\mathrm{PM}_{10}$. Grids with emission increases for these six species are mainly located in areas projected to have high population growth (e.g., Los Angeles and Atlanta). Among the six species, $\mathrm{NO}_{x}$ and $\mathrm{SO}_{2}$ show reductions of more than a factor of 2 in many areas because of control requirements on electricity production, transportation, and many industrial sources. Emissions of $\mathrm{CO}$, VOCs, $\mathrm{PM}_{2.5}$ and $\mathrm{PM}_{10}$ also fall across most of the domain.

\subsection{Region-to-county growth disaggregation}

Next, we evaluate the effect of disaggregating regional growth factors to the county level by examining the differences between Future and FutureRegGF. Grid-cell-level FD values are shown in Fig. 9 for the six projected pollutants. The spatial distribution of FD indicates that regional-tocounty disaggregation results in increased emissions around urban areas (e.g., Los Angeles, Las Vegas and Dallas in the west and Atlanta in the Southeast) as those areas expand into surrounding counties. Many grid cells at the fringe of large urban areas have FD values exceeding $30 \%$, indicating
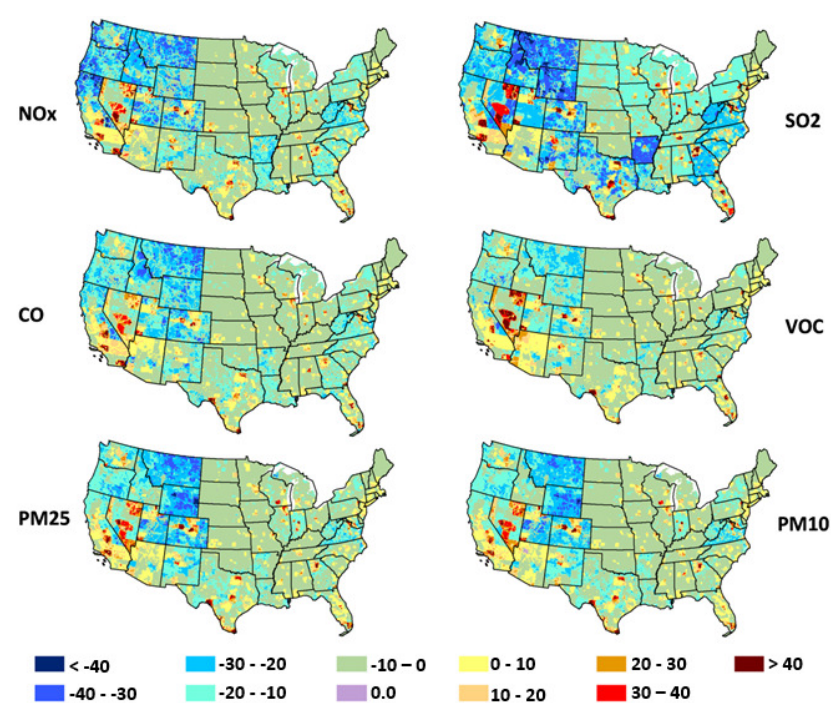

Figure 9. FD (\%) of annual 2050 emissions, Future minus Futur$e R e g G F$, for grid cells in the CONUS $12 \mathrm{~km}$ domain. (Future: 2050 inventory, 2050 surrogates, county growth factors; FutureRegGF: 2050 inventory, 2050 surrogates, regional growth factors).

a large increase in emissions as a result of using county-level growth factors. Large reductions in emissions, indicated by FD values $\leq-20 \%$, are particularly obvious in rural areas in the west and south regions. Using county growth factors has high impacts on emission allocations in the regions of the west and south, particularly for $\mathrm{SO}_{2}$.

Another way to analyze FD results is to calculate mean FD (MFD) values across grid cells with common characteristics. For example, in Fig. 10, we provide MFDs for each pollutant over grid cells that are in the same population density range.

For areas with greater density, the trend is that emission differences become increasingly positive, reflecting that ICLUS population algorithm typically results in migration of people to more dense areas. However, as described above, the ICLUS predicts continued urban sprawl such that the positive MFD in the urban cores (population density $>=200 \mathrm{k}$ gridcell ${ }^{-1}$, about $1400 \mathrm{~km}^{-2}$ ) is slightly less than in the more moderately dense areas, where density is between 130 and $200 \mathrm{k}$ grid-cell $^{-1}$. Thus, projecting emission changes by region without using the county growth allocation method significantly underestimates the future emissions in the more populated areas.

\subsection{Updating emission surrogates}

Next, we evaluate the effects of adjusting future surrogates by comparing Future and Future05Surr. The two gridded emission files were generated from the same 2050 countylevel emission growth factors but using ICLUS-derived surrogates for 2050 and 2005, respectively. Thus, emission differences are introduced only from different spatial surro- 


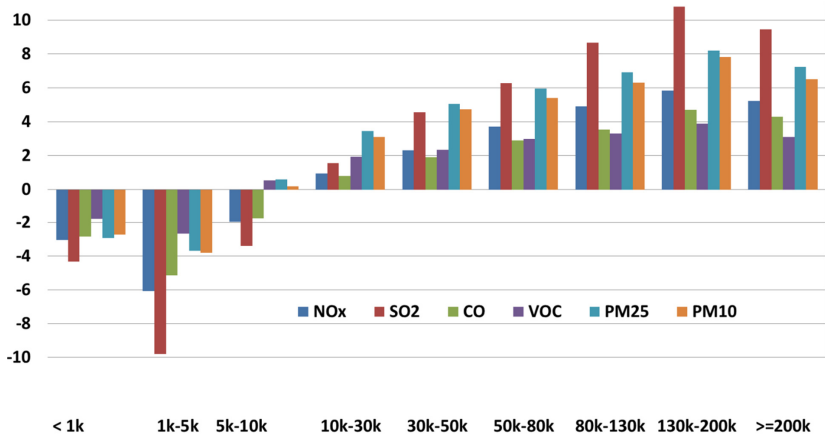

Figure 10. MFD (\%) of 2050 annual emissions, Future minus FutureRegGF, stratified by grid-cell population for 2050. (Future: 2050 inventory, 2050 surrogates, county growth factors; Futur$e \operatorname{Reg} G F$ : 2050 inventory, 2050 surrogates, regional growth factors).

gates. Figure 11 presents the resulting FD values for the six projected pollutants.

In Fig. 11, it is apparent that large increases (FD $\geq 20 \%$ ) often occur in the grid cells surrounding large cities. Furthermore, FD percentage increases are particularly obvious in the west and southwest regions, where urban expansion moves into previously low density grid cells. The counties in these regions tend to be large; thus, changes in spatial surrogates affect a larger number of grid cells. In contrast, changes in gridded emissions tend to be less pronounced in areas with small counties that are closer in size to the $12 \times 12 \mathrm{~km}$ grid cells. Updating the spatial surrogates has a small or negligible impact in rural areas with limited urbanization. Among the six species compared, $\mathrm{SO}_{2}$ has the least changes. $\mathrm{SO}_{2}$ emissions from mobile sources would have been reduced considerably by regulations limiting sulfur content in fuels. Most of the remaining $\mathrm{SO}_{2}$ emissions originate from electricity production and industrial sources. In the ESP v2.0 method, we do not adjust the spatial surrogates for either category, assuming that they are not correlated with population. In contrast, incorporating the 2050 surrogates has particularly high impacts on $\mathrm{CO}$ and VOCs. Major sources for these pollutants are the transportation, residential and commercial sectors, all of which are linked to population- and land-usebased surrogates.

Figure 12 also provides an indication of how updating surrogates affects emissions by land use class. MFDs for each of the six pollutants by 2050 population density ranges are shown in Fig. 12. This figure indicates a complicated relationship. There is a small decrease in emissions in rural areas and a larger decrease in the densest areas. Conversely, there is an increase in emissions from categories ranging in density from 5 to $80 \mathrm{k}$ per cell. Thus, emission modeling using 2050 surrogates allocates more emissions to the suburban areas as they densify, while emissions allocated to the high density urban core grid cells are reduced. This does not mean that populations in cities are projected to decline but rather that

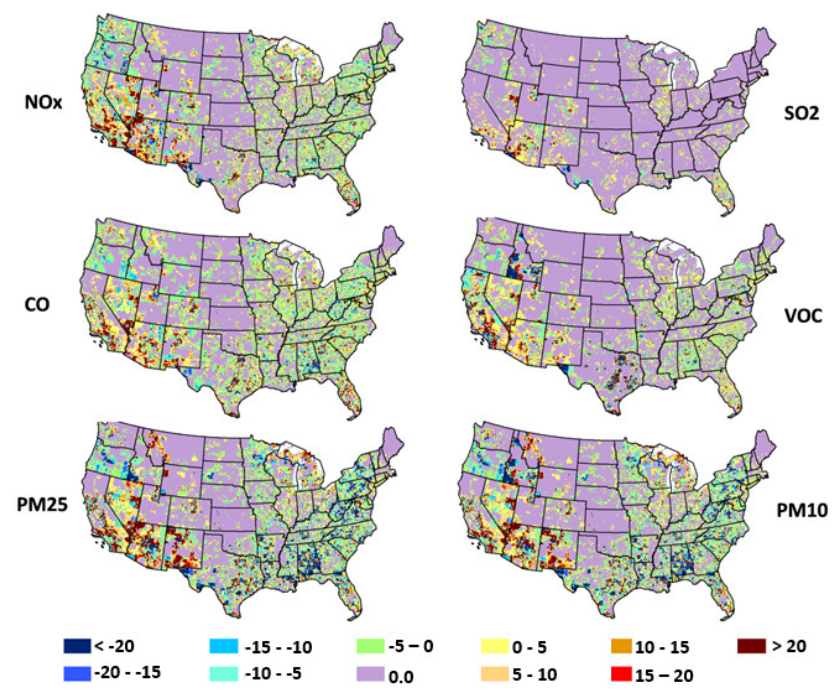

Figure 11. FD (\%) of annual 2050 emissions, Future minus $F u$ ture05Surr, for grid cells in the CONUS $12 \mathrm{~km}$ domain. (Future: 2050 inventory, 2050 surrogates, county growth factors; $F u$ ture05Surr: 2050 inventory, 2005 surrogates, county growth factors).

the projected urban emissions are partially redistributed to the fringe areas since county emission totals are the same for both scenarios. This analysis demonstrates that the common practice of projecting future emissions without projecting future surrogates can lead to over-prediction of urban core emissions and under-prediction of suburban/exurban emissions.

\section{Conclusions}

Gridded emission data are key inputs to air quality models. Pollutant growth factors play a dominant role in determining regional emission and air quality patterns (Tao et al., 2007; Avise et al., 2012). It is commonplace in such applications to apply these growth factors such that emissions grow in place. In this paper, we demonstrate that the region-to-county growth factor disaggregation and county-to-grid allocation approaches included in ESP v2.0 yield a different spatial pattern of emissions. For a given population and land use change scenario, the region-to-county growth disaggregation enables the distinction of different growth levels among counties, and updating spatial surrogates provides a more realistic mapping of emissions to grid cells.

Conversely, growing residential emissions in place and applying current spatial surrogates to future-year emissions may result in an over-prediction of urban core emissions and under-prediction of suburban emissions. Thus, ignoring these shifts may overstate future improvements in human exposure and health risk due to air pollution mitigation as more dense 


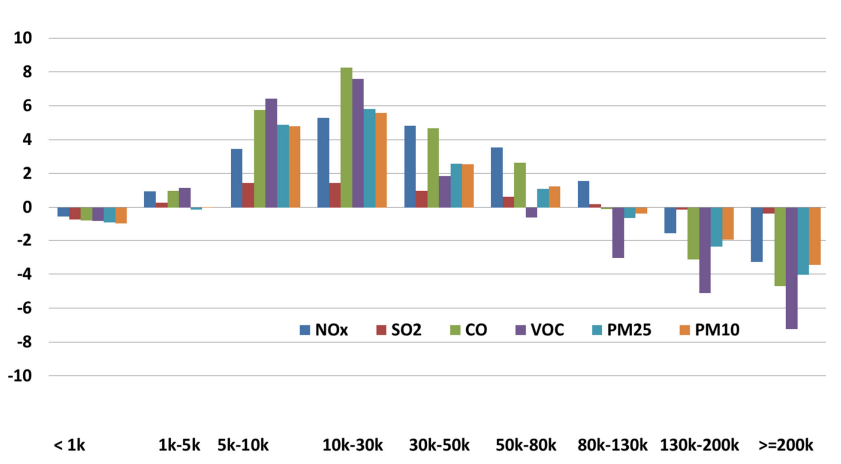

Figure 12. MFD (\%) of 2050 annual emissions, Future minus $\mathrm{Fu}$ ture05Surr, stratified by 2050 grid-cell population. (Future: 2050 inventory, 2050 surrogates, county growth factors; Future05Surr: 2050 inventory, 2005 surrogates, county growth factors).

urban cores yield greater opportunities for human exposures (e.g., Post et al., 2012; West et al., 2013; Silva et al., 2013).

There are many uncertainties in future air quality studies associated with emissions, climate, and changes of landscape. Improving emission allocation in SMOKE will help reduce uncertainties in outcomes (e.g., $\mathrm{O}_{3}$ and $\mathrm{PM}_{2.5}$ concentrations and climate forcing from gases and aerosols) from regional climate and air quality modeling systems such as the coupled WRF/CMAQ (Wong et al., 2012) and help improve confidence in making air quality policies related to human health and environment. Another important aspect of the approach presented here is that it could be applied to examine alternative development scenarios. For example, a smart growth scenario would project greater growth factors in cities and less in suburban/exurban areas than the BAU scenario on which ICLUS was based. Furthermore, within the larger ESP v2.0 framework, emissions and resulting impacts could be examined for wide ranging scenarios that differ in assumptions about population growth and migration, economic growth and transformation, technology change, land use change, and various energy, environmental and land use policies.

While ESP v2.0 represents a state-of-the-art method for generating multi-decadal air pollutant emission projections for non-power sector sources, there are a number of limitations that must be considered in evaluating its utility for specific applications. One such limitation is the current omission of a mechanism to change the spatial distribution of power sector and large industrial emission sources. Spatial re-allocation of these "point" source emissions requires a siting algorithm, the development or application of which is beyond the scope of ESP v2.0. We acknowledge that this is a desirable capability, however, and that considerable research has been conducted in this area (e.g., Cohon et al., 1980; Hobbs et al., 2010; Kraucunas et al., 2015).

Another limitation of ESP v2.0 is that temporal reallocation of emissions is not included at this time. Our re- search suggests that the changing role of technologies and fuels in electricity production may affect seasonal and diurnal emission patterns. For example, natural gas historically has been used within combustion turbines to generate electricity for meeting summer afternoon air conditioning demands. With expanded access to natural gas resources, however, electric utilities are incrementally shifting gas to baseload electricity production. Thus, over the coming decades, the temporal profile of gas-related emissions will change both seasonally and diurnally.

ESP will always be limited by the limitations of its components. The MARKAL energy modeling system, for example, does not account for economic feedbacks associated with changes in energy prices. Also, real-world electric sector decisions are influenced by many factors, some of which act at a much finer resolution than the spatial and temporal resolution of MARKAL. For example, on hot summer days, electric utility dispatch decisions must factor in meteorological conditions that both increase energy demands and tropospheric ozone formation (Chen et al., 2015). Dispatch decisions thus might result in temporal and spatial changes that could not be captured by MARKAL. ESP v2.0 is more suited to longer-range projections with the intent on capturing longterm trends and the multi-decadal effects of transformations in energy, economy and land use. Alternatively, there may be approaches for using ESP in conjunction with a more detailed dispatch model.

Another current limitation is the inability to evaluate the effects of climate change on energy demands. Climaterelated changes currently would need to be evaluated outside of ESP v2.0. However, exogenous estimates of increased energy demands could be input into MARKAL to evaluate how they would affect energy system emissions.

These various limitations are driving our current ESP v3.0 development process. For example, we are working towards generating scenario-specific temporal adjustment factors, and we plan to explore the inclusion of point source siting algorithms. Furthermore, future ESP iterations will incorporate more recent versions of ICLUS and MARKAL and thus utilize updated population, land use, economic, and energy projections, as well as recent emission regulations.

Other possible updates are being considered. To improve compatibility with other long-term projections, it may be advantageous to harmonize the population, land use and energy assumptions with the IPCC's representative concentration pathways (RCPs) (Van Vuuren et al., 2011) and shared socioeconomic scenarios (Van Vuuren et al., 2012). Also, while the baseline spatial surrogates used here were developed in 2000, these could be updated to the 2010 surrogate files that are now used within the EPA's 2011 modeling platform. 


\section{Model and data availability}

Most of the modeling components that comprise this methodology are publically available. SMOKE and the Spatial Allocator can be downloaded from the Community Modeling \& Analysis System Center (http://www.cmascenter. org). ICLUS modeling tools and land use projections can be obtained from the US EPA (http://www.epa.gov/ncea/ global/iclus/). The MARKAL model is distributed by the Energy Technology Systems Analysis Program of the International Energy Agency (http://www.iea-etsap.org). Executing MARKAL requires licensing and additional software. Please contact Dan Loughlin (loughlin.dan@epa.gov) for information about obtaining the US EPA's database, which allows MARKAL to be applied to the US energy system. The EPA's MARKAL nine-region database used in this study, as well as more recent versions, are available upon request at no cost. Regional- and county-level emission growth factors and surrogate shapefiles for 2005 and 2050 are available for download in the Supplement.

\section{The Supplement related to this article is available online at doi:10.5194/gmd-8-1775-2015-supplement.}

Author contributions. Limei Ran was the lead author and the lead in designing, implementing and demonstrating the spatial allocation component of ESP 2.0. Dan Loughlin conceived of the project and was instrumental in developing the spatial allocation method. Furthermore, he provided the emission growth and control factors used to develop the future-year inventory. Dongmei Yang, Zach Adelman and B. H. Baek assisted with the development and implementation of the method, including applications of the various emissions modeling components. Chris Nolte was instrumental in developing ESP 1.0 and contributed to this effort through a thorough review and constructive comments on this manuscript.

Acknowledgements. Much of the effort of developing, implementing and demonstrating the spatial allocation method embodied in ESP 2.0 was funded by the US Environmental Protection Agency Office of Research and Development. Alison Eyth, of the US EPA's Office of Air Quality Planning and Standards, contributed to a previous implementation of the spatial allocation method. ICLUSrelated land use projections were provided by Phil Morefield and Britta Bierwagen of the US EPA's National Center for Environmental Assessment (NCEA). William Benjey helped develop ESP v1.0 and reviewed this manuscript. Others contributing the emission growth factor projections are current and past members of the Office of Research and Development Energy and Climate Assessment Team, including Carol Lenox, Rebecca Dodder, Ozge Kaplan and William Yelverton.
Disclaimer. While this work has been reviewed and cleared for publication by the US EPA, the views expressed here are those of the authors and do not necessarily represent the official views or policies of the Agency. Mention of software and organizations does not constitute an endorsement.

Edited by: J. Williams

\section{References}

Akhtar, F., Pinder, R., Loughlin, D., and Henze, D.: GLIMPSE: A rapid decision framework for energy and environmental policy, Environ. Sci. Technol., 47, 12011-12019, doi:10.1021/es402283j, 2013.

Avise, J., Chen, J., Lamb, B., Wiedinmyer, C., Guenther, A., Salathé, E., and Mass, C.: Attribution of projected changes in summertime US ozone and PM2.5 concentrations to global changes, Atmos. Chem. Phys., 9, 1111-1124, doi:10.5194/acp9-1111-2009, 2009.

Avise, J., Gonzalez-Abraham, R., Chung, S. H. Chen, J., Lamb, B., Salathé, E. P., Zhang, Y., Nolte, C. G., Loughlin, D. H., Guenther, A., Wiedinmyer, C., and Duhl, T.: Evaluating the effects of climate change on summertime ozone using a relative response factor approach for policymakers, J. Air Waste Ma., 62, 10611074, doi:10.1080/10962247.2012.696531, 2012.

Bierwagen, B. G., Theobald, D. M., Pyke, C. R., Choate, A., Groth, P., Thomas, J. V., and Morefield, P.: National housing and impervious surface scenarios for integrated climate impact assessments, P. Natl. Acad. Sci. USA, 107, 20887-20892, doi:10.1073/pnas.1002096107, 2010.

Byun, D. and Schere, K.: Review of the governing equations, computational algorithms, and other components of the Models-3 Community Multiscale Air Quality (CMAQ) modeling system, Appl. Mech. Rev., 59, 51-77, doi:10.1115/1.2128636, 2006.

Chen, Y., Hobbs, B. F., Ellis, J. H., Crowley, C., and Joutz, F.: Impacts of climate change on power sector $\mathrm{NO}_{x}$ emissions: A longrun analysis of the US mid-atlantic region, Energ. Policy, 84, 1121, doi:10.1016/j.enpol.2015.04.013, 2015.

Cohon, J. L., ReVelle, C. S., Current, J., Eagles, T., Eberhart, R., and Church, R.: Application of a multiobjective facility location model to power plant siting in a six-state region of the U.S., Comput. Oper. Res., 7, 107-123, doi:10.1016/0305-0548(80)900192, 1980

Fishbone, L. G. and Abilock, H.: MARKAL: A linear programming model for energy-systems analysis: technical description of the BNL version, Int. J. Energ. Res., 5, 353-375, doi:10.1002/er.4440050406, 1981.

Gao, Y., Fu, J. S., Drake, J. B., Lamarque, J.-F., and Liu, Y.: The impact of emission and climate change on ozone in the United States under representative concentration pathways (RCPs), Atmos. Chem. Phys., 13, 9607-9621, doi:10.5194/acp-13-96072013, 2013.

Hobbs, B. F., Hu, M.-C., Ellis, J. H., Paul, A., Burtraw, D., and Palmer, K. L.: From regions to stacks: Spatial and temporal downscaling of future pollution scenarios for the power sector, IEEE T. Power Syst., 25, 1179-1189, doi:10.1109/TPWRS.2009.2036801, 2010. 
Hogrefe, C., Lynn, B., Civerolo, K., Ku, J.-Y., Rosenthal, J., Rosenzweig, C., Goldberg, R., Gaffin, S., Knowlton, K., and Kinney, P. L.: Simulating changes in regional air pollution over the eastern United States due to changes in global and regional climate and emissions, J. Geophys. Res., 109, D22301, doi:10.1029/2004JD004690, 2004.

Houyoux, M. R., Vukovich, J. M., Coats, C. J., Wheeler, N. J., and Kasibhatla, P. S.: Emission inventory development and processing for the Seasonal Model for Regional Air Quality (SMRAQ) project, J. Geophys. Res.-Atmos., 105, 9079-9090, doi:10.1029/1999JD900975, 2000.

Houyoux, M. R., Strum, M., Mason, R., and Eyth, A.: Data management using the emissions modeling framework, in: Proceedings of the 15th International Emission Inventory Conference, 15-18 May, New Orleans, LA, 2006.

Kraucunas, I., Clarke, L., Dirks, J., Hathaway, J., Hejazi, M., Hibbard, K., Huang, M., Jin, C., Kintner-Meyer, M., Kleese van Dam, K., Leung, R., Li, H.-Y., Moss, R., Peterson, M., Rice, J., Scott, M., Thomson, A., Voisin, N., and West, T: Investigating the nexus of climate, energy, water, and land at decisionrelevant scales: The Platform for Regional Integrated Modeling and Analysis (PRIMA), Climatic Change, 129, 573-588, doi:10.1007/s10584-014-1064-9, 2015.

Lenox, C., Dodder, R., Gage, C., Kaplan, O., Loughlin, D., and Yelverton, W.: EPA US Nine Region MARKAL Database, Database Documentation, US Environmental Protection Agency, Washington, D.C., No: EPA600/B1-13/203, 2013.

Loughlin, D. H., Benjey, W. G., and Nolte, C. G.: ESP v1.0: methodology for exploring emission impacts of future scenarios in the United States, Geosci. Model Dev., 4, 287-297, doi:10.5194/gmd-4-287-2011, 2011.

Loulou, R., Goldstein, G., and Noble, K.: Documentation for the MARKAL family of models, IEA Energy Technology Systems Analysis Programme, Paris, France, 2004.

Morris, R. E., Koo, B., Guenther, A., Yarwood, G., McNally, D., Tesche, T. W., Tonnesen, G., Boylan, J., and Brewer, P.: Model sensitivity evaluation for organic carbon using two multipollutant air quality models that simulate regional haze in the southeastern United States, Atmos. Environ., 40, 4960-4972, doi:10.1016/j.atmosenv.2005.09.088, 2006.

Nakicenovic, N. and Swart, R. (Eds.): IPCC 2000, Intergovernmental Panel on Climate Change (IPCC): Special Report on Emissions Scenarios, Cambridge Univ. Press, New York, 2000.

Nolte, C. G., Gilliland, A. B., Hogrefe, C., and Mickley, L. J.: Linking global to regional models to assess future climate impacts on surface ozone levels in the United States, J. Geophys. Res.Atmos., 113, D14307, doi:10.1029/2007JD008497, 2008.

Post, E. S., Grambsch, A., Weaver, C., Morefield, P., Huang, J., Leung, L.-Y., Nolte, C. G., Adams, P., Liang, X.-Z., Zhu, J.-H., and Mahoney, H.: Variation in estimated ozone-related health impacts of climate change due to modeling choices and assumptions, Environ. Health Persp., 120, 1559-1564, doi:10.1289/ehp.1104271, 2012.

Ran, L. R.: Emissions Modeling Framework Surrogate Tool: User's Guide, the Community Modeling and System analysis at the University of North Carolina, Chapel Hill, 2014, available at: https: //www.cmascenter.org/sa-tools/documentation/4.2/html/, last access: June 2015.
Silva, R. A., West, J. J., Zhang, Y., Anenberg, S. C., Lamarque, J. F., Shindell, D. T., Collins, W. J., Dalsoren, S., Faluvegi, G., Folberth, G., Horowitz, L. W., Nagashima, T., Naik, V., Rumbold, S., Skeie, R., Sudo, K., Takemura, T., Bergmann, D., CameronSmith, P., Cionni, R., Doherty, R. M., Eyring, V., Josse, B., MacKenzie, W. A., Plummer, D., Righi, M., Stevenson, D. S., Strode, S., Szopa, S., and Zeng, G.: Global premature mortality due to anthropogenic outdoor air pollution and the contribution of past climate change, Environ. Res. Lett., 8, 034005, doi:10.1088/1748-9326/8/3/034005, 2013.

Tagaris, E., Manomaiphiboon, K., Liao, K. J., Leung, L. R., Woo, J. H., He, S., Amar, P., and Russell, A. G.: Impacts of global climate change and emissions on regional ozone and fine particulate matter concentrations over the United States, J. Geophys. Res., 112, D14312, doi:10.1029/2006JD008262, 2007.

Tao, Z., Williams, A., Huang, H. C., Caughey, M., and Liang, X. Z.: Sensitivity of US surface ozone to future emissions and climate changes, Geophys. Res. Lett., 34, L08811, doi:10.1029/2007GL029455, 2007.

Theobald, D. M.: Landscape Patterns of Exurban Growth in the USA from 1980 to 2020, Ecol. Soc., 10, 32, 2005.

Trail, M., Tsimpidi, A. P., Liu, P., Tsigaridis, K., Rudokas, J., Miller, P., Nenes, A., Hu, Y., and Russell, A. G.: Sensitivity of air quality to potential future climate change and emissions in the United States and major cities, Atmos. Environ., 94, 552-563, doi:10.1016/j.atmosenv.2014.05.079, 2014.

UNC: Operational guidance for the Community Multiscale Air Quality (CMAQ) modeling system: Version 5.0 (February 2012 release), Community Modeling and Analysis System, Institute for the Environment, University of North Carolina, Chapel Hill, NC, 2012.

UNC: Spatial Allocator Version 4.2, the Community Modeling and System analysis at the University of North Carolina, Chapel Hill, NC, 2014a.

UNC: SMOKE v3.6 User's Manual, University of North Carolina, Chapel Hill, NC, 2014b.

US EIA: Annual Energy Outlook 2006 with projections to 2030, US Energy Information Administration, Washington, D.C., No: DOE/EIA-0383(2010), 2006.

US EIA: Annual Energy Outlook 2010 with projections to 2035, US Energy Information Administration, Washington, D.C., No: DOE/EIA-0383, 2010.

US EPA: Land-Use Scenarios: National-Scale Housing-Density Scenarios Consistent with Climate Change Storylines, An interim report of the US EPA Global Change Research Program, US Environmental Protection Agency, National Center for Environmental Assessment, Washington, D.C., EPA/600/R-08/076F, 2009a.

US EPA: Assessment of the Impacts of Global Change on Regional U.S. Air Quality: A Synthesis of Climate Change Impacts on Ground-Level Ozone - US EPA Global Change Research Program, US Environmental Protection Agency, National Center for Environmental Assessment, Washington, D.C., 2009b.

US EPA: 2005 National Emissions Inventory data and documentation, US Environmental Protection Agency, Washington, D.C., 2010.

US EPA: Emissions Inventory Final Rule Technical Support Document (TSD), US Environmental Protection Agency, Office of 
Air and Radiation, Office of Air Quality Planning and Standards, Research Triangle Park, NC, 2011.

US EPA: Emissions Modeling Clearinghouse - Spatial Allocation, US Environmental Protection Agency, available at: http://www. epa.gov/ttn/chief/emch/spatial/, last access: April 2014a.

US EPA: DRAFT Technical Support Document: Preparation of emission inventories for the Version 6.0, 2011 Emission Modeling Platform, US Environmental Protection Agency, Office of Air and Radiation, 2014b.

Van Vuuren, D. P., Edmonds, J., Kainuma, M., Riahi, K., Thmsom, A., Hibbard, K., Hurtt, G. C., Kram, T., Krey, V., Lamarque, J.F., Masui, T., Meinshausen, M., Nakicenovic, N., Smith, S. J., and Rose, S. K.: The representative concentration pathways: an overview, Climatic Change, 109, 5-31, doi:10.1007/s10584-0110148-z, 2011.

Van Vuuren, D. P., Riahi, K., Moss, R., Edmonds, J., Thomson, A., Nakicenovic, N., Kram, T., Berkhout, F., Swart, R., Janetos, A., Rose, S. K., and Arnell, N.: A proposal for a new scenario framework to support research and assessment in different climate research communities, Global Environ. Chang., 22, 21-35, doi:10.1016/j.gloenvcha.2011.08.002, 2012.

Weaver, C. P., Cooter, E., Gilliam, R., Gilliland, A., Grambsch, A., Grano, D., Hemming, B., Hunt, S. W., Nolte, C., Winner, D. A., Liang, X.-Z., Zhu, J., Caughey, M., Kunkel, K., Lin, J.-T., Tao, Z., Williams, A., Wuebbles, D. J., Adams, P. J., Dawson, J. P., Amar, P., He, S., Avise, J., Chen, J., Cohen, R. C., Goldstein, A. H., Harley, R. A., Steiner, A. L., Tonse, S., Guenther, A., Lamarque, J.-F., Wiedinmyer, C., Gustafson, W. I., Leung, L. R., Hogrefe, C., Huang, H.-C., Jacob, D. J., Mickley, L. J., Wu, S., Kinney, P. L., Lamb, B., Larkin, N. K., McKenzie, D., Liao, K.-J., Manomaiphiboon, K., Russell, A. G., Tagaris, E., Lynn, B. H., Mass, C., Salathé, E., O’neill, S. M., Pandis, S. N., Racherla, P. N., Rosenzweig, C., and Woo, J.-H.: A preliminary synthesis of modeled climate change impacts on U.S. regional ozone concentrations, B. Am. Meteorol. Soc., 90, 1843-1863, doi:10.1175/2009BAMS2568.1, 2009.
West, J. J., Smith, S. J., Silva, R. A., Naik, V., Zhang, Y., Adelman, Z., Fry, M. M., Anenberg, S., Horowitz, L.-W., and Lamarque, J.-F.: Co-benefits of mitigating global greenhouse gas emissions for future air quality and human health, Nat. Clim. Change, 3, 885-889, doi:10.1038/nclimate2009, 2013.

Wong, D. C., Pleim, J., Mathur, R., Binkowski, F., Otte, T., Gilliam, R., Pouliot, G., Xiu, A., Young, J. O., and Kang, D.: WRFCMAQ two-way coupled system with aerosol feedback: software development and preliminary results, Geosci. Model Dev., 5, 299-312, doi:10.5194/gmd-5-299-2012, 2012.

Woo, J. H., He, S., Tagaris, E., Liao, K. J., Manomaiphiboon, K., Amar, P., and Russell, A. G.: Development of North American emission inventories for air quality modeling under climate change, J. Air Waste Ma., 58, 1483-1494, 2008.

Zhang, Y., Liu, X. H., Olsen, K. M., Wang, W. X., Do, B. A., and Bridgers, G. M.: Responses of future air quality to emission controls over North Carolina, Part II: Analyses of future-year predictions and their policy implications, Atmos. Environ., 44, 2767 2779, doi:10.1016/j.atmosenv.2010.03.022, 2010. 